\title{
A bricolage perspective on service innovation
}

\author{
Lars Witell ${ }^{\mathrm{a}, *}$, Heiko Gebauer ${ }^{\mathrm{b}}$, Elina Jaakkola ${ }^{\mathrm{c}}$, Wafa Hammedi ${ }^{\mathrm{d}}$, Lia Patricio ${ }^{\mathrm{e}}$, Helen Perks ${ }^{\mathrm{f}}$ \\ a CTF, Service Research Center, Karlstad University and Linköping University, Sweden \\ ${ }^{\mathrm{b}}$ EAWAG, Switzerland \\ c Turku School of Economics, University of Turku, Finland \\ ${ }^{\mathrm{d}}$ University of Namur, Belgium \\ e Faculty of Engineering, University of Porto, Portugal \\ ${ }^{\mathrm{f}}$ University of Nottingham, UK
}

\section{A R T I C L E I N F O}

\section{Article history:}

Received 15 November 2016

Received in revised form 23 March 2017

Accepted 24 March 2017

Available online 1 April 2017

\section{Keywords:}

Service innovation

Bricolage

Entrepreneurship

Resource-constrained environments

Social innovation

Capabilities

\begin{abstract}
A B S T R A C T
Service innovation is often viewed as a process of accessing the necessary resources, (re)combining them, and converting them into new services. The current knowledge on success factors for service innovation, such as formalized new service development (NSD) processes, predominantly comes from studying large firms with a relatively stable resource base. However, this neglect situations in which organizations face severe resource constraints. This paper argues that under such constraints, a formalized new service development process could be counter-productive and a bricolage perspective might better explain service innovation in resourceconstrained environments. In this conceptual paper, we propose that four critical bricolage capabilities (addressing resource scarcity actively, making do with what is available, improvising when recombining resources, and networking with external partners) influence service innovation outcomes. Empirical illustrations from five organizations substantiate our conceptual development. Our discussion leads to a framework and four testable propositions that can guide further service research.
\end{abstract}

(C) 2017 Elsevier Inc. All rights reserved.

\section{Introduction}

Service innovation, which remains a key priority in service research (Ostrom et al., 2015; Witell, Snyder, Gustafsson, Fombelle, \& Kristensson, 2016), emphasizes that a sustainable competitive advantage depends on the development and introduction of new services (Gebauer, Gustafsson, \& Witell, 2011). Reflecting the rise of a service-centered approach to value creation, service innovation research has broadened its focus to address new value creation logics represented by companies such as Google, IKEA, and Airbnb, and targeted new empirical fields such as manufacturing industry, the public sector, and social organizations at the bottom of the pyramid (e.g., Gebauer \& Reynoso, 2013; Lusch, Vargo, \& O'Brien, 2007; Michel, Brown, \& Gallan, 2008). This change in context has introduced challenges to the key assumptions in existing research on service innovation.

According to the contemporary view, a service innovation is a novel (re)combination of resources (Gallouj \& Weinstein, 1997; Lusch \& Nambisan, 2015). The extant literature assumes, at least implicitly, that organizations have access to the necessary resources, which they (re)combine and, finally, convert into service innovations. Thus, new

\footnotetext{
* Corresponding author.

E-mail address: lars.witell@kau.se (L. Witell).
}

service development (NSD) research has focused on how firms can do this effectively, advocating the use of formalized NSD processes along the design, analysis, development, and launch stages (Froehle, Roth, Chase, \& Voss, 2000; Papastathopoulou \& Hultink, 2012). The rationale is that formalization increases the efficiency and effectiveness of the NSD process, which is positively associated with service innovation outcomes (Storey, Cankurtaran, Papastathopoulou, \& Hultink, 2016).

The present paper challenges the current focus on developing effective processes for (re)combining resources and shifts attention toward resource scarcity (Cunha, Oliveira, Rosado, \& Habib, 2014). The newly emerging empirical fields for service innovation represent environments where different forms of resource constraints are prevalent (Fuglsang, 2010; Linna, 2013). For example, the manufacturing industry reportedly lacks resources regarding digitization and the Internet of Things (IoT), which has led to failure in innovating new services that utilize these technologies (Spring \& Araujo, 2016). The public sector has resource deficits when it comes to understanding customers (Fuglsang, 2010), while social organizations operating in low-income countries face naturally resource-constrained environments (Srinivas \& Sutz, 2008). While many organizations often innovate in such conditions, previous research has paid little attention to the implications of resource constraints on service innovation.

To address this shortcoming, we look beyond extant service innovation research and employ the concept of bricolage to explain how 
organizations innovate services in resource scarce environments. Bricolage refers to solving problems and taking advantage of opportunities by combining resources at hand (Baker \& Nelson, 2005) and can be contrasted with behaviors that involve seeking new resources to address new situations or opportunities (Duymedjian \& Rüling, 2010). We consider the bricolage concept as a set of capabilities related to improvisation and making do with what resources are available. The bricolage concept originates from technology and product innovation research, but has rarely been applied in research on service innovation. From a bricolage perspective, firms view scarcity as an opportunity, which makes it a suitable conceptual lens for extending research on service innovation (Salunke, Weerawardena, \& McColl-Kennedy, 2013).

The present article makes four theoretical contributions. First, we shift the attention of service innovation research from resource-rich to resource-constrained environments, and suggest that bricolage is a key perspective in understanding service innovation in such environments. Second, we propose four specific bricolage capabilities (addressing resource scarcity actively, making do with what is available, improvising when recombining resources, and networking with external partners) that influence service innovation outcomes in resourceconstrained environment. Third, our analysis is summarized in four testable propositions, which can guide and be tested by future service research. Fourth, we suggest potential contingencies for the impact of such bricolage capabilities, thereby extending the extant knowledge on the bricolage concept.

\section{Literature review}

\subsection{Service innovation}

\subsubsection{Service innovation as a novel combination of resources}

In its early days, service innovation research mainly discussed differences between product and service innovation (Johne \& Storey, 1998; Snyder, Witell, Gustafsson, Fombelle, \& Kristensson, 2016). Service innovation was perceived as inherently different from product innovation by virtue of being incremental and continuous in nature, explaining the absence of distinct "developmental stages" and research and development (R\&D) departments in service firms (Johne \& Storey, 1998). More recently, service research has developed new conceptualizations of service innovation, building on service-centered approaches to value creation (Lusch \& Nambisan, 2015). These service-centered approaches suggest that service innovations are not only incremental and continuous improvements, but can be both radical and disruptive, creating a leap in customer value (de Brentani, 2001; Michel et al., 2008).

Accordingly, service innovation concerns recombining resources in novel ways. In other words, service innovation can be viewed as "the rebundling of diverse resources that create novel resources that are beneficial ... to some actors in a given context" (Lusch \& Nambisan, 2015 p. 161) or as "the collaborative recombination of practices that provide novel solutions for new or existing problems" (Vargo, Wieland, \& Akaka, 2015 p. 64). This follows a Schumpeterian view of innovating, suggesting that it concerns "carrying out of new combinations" (Schumpeter, 1934 p. 66). Service innovation takes advantage of new combinations of resources derived from existing technology and knowledge. Service innovation often starts with a change in a resource that then opens up to new combinations. In line with recent conceptualizations in service research, we view all innovations as recombinations of existing and new resources.

\subsubsection{The NSD process}

While the incremental and continuous nature of service innovation initially explained the absence of distinct "developmental stages", research later agreed that service innovation benefits from formalizing the NSD process as well as employing deliberate and structured approaches for involving customers, employees, suppliers, and partners (de Brentani, 2001; Storey et al., 2016). Most studies on success factors have recommended establishing a formalized NSD process, and several researchers have regarded the NSD process as the most important success factor (Biemans, Griffin, \& Moenaert, 2015). A recent meta-analysis highlighted the importance of both the effectiveness and the efficiency of the NSD process (Storey et al., 2016). Furthermore, previous studies have empirically demonstrated that the formalization of the NSD process shortens time-to-market (Froehle et al., 2000).

The formalization of the NSD process is a vital element for service innovation (Cooper \& de Brentani, 1991; de Brentani, 2001; Storey \& Easingwood, 1998). Most process models in the NSD literature contain the four stages of design, analysis, development, and full launch. The more elaborate and formalized NSD process, the higher the performance (Melton \& Hartline, 2015). NSD models are often based on a stage-gate model, with suggestions on which methods to use in different stages (Edvardsson, Meiren, Schäfer, \& Witell, 2013). Indeed, the better organizations formalize the tasks involved in developing new services, the easier it is to replicate, convey, and improve them (Ferdows, 2006). However, there is a duality of the service innovation process; that is, process formalization can improve effectiveness and efficiency, but it can also inhibit creativity and lead to less innovative services. Table 1 summarizes previous research findings on the role of formalization of NSD processes in service innovation.

\subsection{Bricolage in resource-constrained environments}

\subsubsection{Innovation and resource scarcity}

Resources are the tangible and intangible assets that firms use to develop and implement their strategies (Ray, Barney, \& Muhanna, 2004). Innovating depends less on finding optimal combinations of resources than it does on using, for development tasks, resources that are hidden, scattered, or badly utilized (Hirschman, 1958). Resources appear to be particularly important for services because service innovation starts with a change in a resource that then opens up to new combinations of resources. In many situations, service innovation occurs in resourceconstrained environments.

Resource scarcity is not a uniform concept. First, the focal firm trying to innovate the service might have internal resource constraints (Gupta, Smith, \& Shalley, 2006). A firm can have too few employees with a certain capability, the employees could be situated in the wrong organizational unit, or their capabilities could be outdated. Second, resource constraints can occur at the customer's end. Customers might lack the financial resources to afford the use of services (Cunha et al., 2014) or the competences to participate in the design and testing of service innovations (Gebauer \& Reynoso, 2013). Third, resource constraints can occur in the business environment when other organizations lack the resources to partner in NSD or service provision (e.g., Barrett et al., 2015; Srinivas \& Sutz, 2008).

Following Srinivas and Sutz (2008), we refer to resource constraints and/or scarcity in comparative terms, viewing scarcity either quantitatively or qualitatively. Organizations often experience scarcity when they try to attract specific human, financial, or other resources when they are needed (Baker \& Nelson, 2005). Resource scarcity have been discussed in different literature streams, including organizational behavior, innovation, and entrepreneurship. We view resource constraints as the lack of a resource needed for innovating (Cunha et al., 2014). Research into resource constraints has either discussed the matter on a general level (Staw, 1980 or addressed the scarcity of specific resources such as financial, technical, human, and time (Cunha et al., 2014). In addition, research has discussed scarcity in institutions and infrastructure (Barrett et al., 2015) or addressed knowledge and skills as a specific resource of humans (Baker \& Nelson, 2005).

\subsubsection{Bricolage}

The bricolage concept originates from technology and product innovation, but has rarely been applied to service innovation, see Table 2 . It was originally introduced by Levi-Strauss (1966), who basically contrasted engineers with bricoleurs. While engineers follow specific 
Table 1

Formalization of the development process in new service development (NSD).

\begin{tabular}{|c|c|c|}
\hline Authors & Type of study & Description \\
\hline Cooper and de Brentani (1991) & Survey & $\begin{array}{l}\text { Execution of activities in the launch phase, marketing, technical activities, and pre-development activities is strongly linked } \\
\text { to success. }\end{array}$ \\
\hline Storey and Easingwood (1998) & Survey & $\begin{array}{l}\text { The process of developing a new product and overcoming various barriers (administrative, legal, and operational) } \\
\text { generates a general development expertise that can be used for further development. }\end{array}$ \\
\hline Froehle et al. (2000) & Survey & $\begin{array}{l}\text { Formalization of the NSD process enables replication and cycle time reduction. Firms with formal NSD processes are more } \\
\text { likely to outperform competitors by taking advantage of a "first mover" advantage. }\end{array}$ \\
\hline de Brentani (2001) & Survey & A well-planned NSD process can provide important benefits, particularly when developing incremental new service offerings. \\
\hline Stevens and Dimitriadis (2004) & Case study & $\begin{array}{l}\text { The number of stages and the kind of actors involved revealed no linear development pattern, but rather a weakly } \\
\text { structured NSD process. }\end{array}$ \\
\hline Edvardsson et al. (2013) & Survey & $\begin{array}{l}\text { A formalized development process tends to produce higher NSD performance due to reduced miscommunication and } \\
\text { eliminate non-value-added activities. }\end{array}$ \\
\hline Melton and Hartline (2015) & Survey & $\begin{array}{l}\text { Process formalization inhibits creativity and service innovation. However, process complexity has a significant, positive } \\
\text { direct impact on service innovation radicalness. }\end{array}$ \\
\hline Biemans et al. (2015) & $\begin{array}{l}\text { Literature } \\
\text { review }\end{array}$ & $\begin{array}{l}\text { The literature does not present a Stage-Gate model for NSD. Such a general model of the NSD process may be contingent } \\
\text { on the service context. }\end{array}$ \\
\hline Storey et al. (2016) & Meta-analysis & $\begin{array}{l}\text { Development efficiency is critical for service innovation performance. For tacit services, there is a greater need for a } \\
\text { formalized NSD process. }\end{array}$ \\
\hline
\end{tabular}

procedures to perform their work, a bricoleur is someone who uses 'whatever is at hand' and this repertoire of resources can be odd and heterogeneous. Bricolage occurs either at the individual level of the entrepreneur (or intrapreneur) or at the organizational level. Since our focus is on organizations, we discuss bricolage at the organizational level. Organizations relying on bricolage can be seen as 'muddling through' (Lindblom, 1959), an approach that directs an organization's decisionmaking in resource-constrained environments (Gatignon \& Xuereb, 1997). Bricolage is about combining strategically existing resources to create unique opportunities and greater value for clients (Baker \& Nelson, 2005; Garud \& Karnøe, 2003).

Bricolage refers to solving problems and taking advantage of opportunities by combining existing resources (Baker \& Nelson, 2005). Bricolage can be contrasted with behaviors involving seeking new resources to address new situations or opportunities (Duymedjian \& Rüling, 2010). The extant literature attributes bricolage to organizations that access resources available to them to circumnavigate certain constraints. Although theories on bricolage and service innovation appear to share a similar underlying logic with respect to recombining resources in a novel manner, bricolage remains a relatively underexplored area in service innovation research (Storey et al., 2016).

\subsubsection{Bricolage capabilities}

We argue that bricolage capability - that is, the ability to deploy a particular form of bricolage - explains why some organizations are more successful than others when facing resource constraints. Bricolage capabilities are embedded into the entrepreneurial process comprising opportunity creation, opportunity development, and exploitation (cf. Vanevenhoven, Winkel, Malewicki, Dougan, \& Bronson, 2011). Various bricolage capabilities enhance the efforts of an organization along this process.

We posit that bricolage is built on the four following capabilities: (i) actively addressing resource scarcity, (ii) making do with what is available, (iii) improvising when recombining resources, and (iv) networking with external partners (Baker \& Nelson, 2005; Fisher, 2012; Linna, 2013).

First, organizations can either address resource constraints actively or avoid this challenge. The latter means that organizations engage in avoidance behaviors or escape from acting under the constraints of resource scarcity (Rosenzweig, Grinstein, \& Ofek, 2016) by abandoning new opportunities, terminating innovation projects, or exiting markets (Baker \& Nelson, 2005). However, through the ability to actively address resource scarcity, firms can seize advantages where competitors may

Table 2

Studies on bricolage in organizations.

\begin{tabular}{|c|c|c|}
\hline Authors & Focus & Description \\
\hline Ciborra (1996) & Entrepreneurial bricolage in high-tech firms & Bricolage contributing to the survival of high-tech firms facing task uncertainty \\
\hline Garud and Karnøe (2003) & $\begin{array}{l}\text { Technology entrepreneurship in newly } \\
\text { emerging wind power industry }\end{array}$ & Bricolage as contrasting approach to technology breakthrough \\
\hline Baker and Nelson (2005) & $\begin{array}{l}\text { Entrepreneurial bricolage in } \\
\text { resource-constrained companies }\end{array}$ & A process model of bricolage and growth \\
\hline Spencer, Murtha, and Lenway (2005) & Bricolage for technological entrepreneurship & $\begin{array}{l}\text { Opportunities and challenges when operating within countries that display four } \\
\text { types of national political institutional structures }\end{array}$ \\
\hline Leybourne and Sadler-Smith (2006) & Organizational bricolage & Bricolage as embedded in improvisation, intuition, and creativity \\
\hline Baker (2007) & Organizational bricolage & Description of the relationship between bricolage and improvisation \\
\hline Andersen (2008) & Entrepreneurial and organizational bricolage & $\begin{array}{l}\text { Bricolage clarifies innovations in emerging, bottom-up processes and utilizes what } \\
\text { is at hand, Pioneering entrepreneurs use incremental processes of problem solving }\end{array}$ \\
\hline Essén (2009) & Organizational bricolage & Individuals' "making do with resources at hand," can trigger service innovation \\
\hline $\begin{array}{l}\text { Engelen, Erturk, Froud, Leaver, and } \\
\text { Williams (2010) }\end{array}$ & Organizational bricolage & Bricolage as a main element for financial innovation \\
\hline Fuglsang and Sørensen (2011) & Organizational bricolage & $\begin{array}{l}\text { Innovation in reality happens as small step 'bricolage'-as a 'do-it-yourself' } \\
\text { problem-solving activity taking place in daily work situations }\end{array}$ \\
\hline Salunke et al. (2013) & Entrepreneurial and organizational bricolage & $\begin{array}{l}\text { Making do by combining resources at hand as higher levels of entrepreneurial } \\
\text { bricolage are associated with higher levels of interactive and supportive innovation }\end{array}$ \\
\hline Halme, Lindeman, and Linna (2012) & Intrapreneurial bricolage & $\begin{array}{l}\text { Intrapreneurial bricolage as creative bundling of scarce resources to help innovators } \\
\text { overcome organizational constraints and to mobilize internal and external resources }\end{array}$ \\
\hline Desa (2012) & Bricolage for social entrepreneurs & Bricolage to reconfigure existing resources at hand \\
\hline $\begin{array}{l}\text { Senyard, Baker, Steffens, and } \\
\text { Davidsson (2014) }\end{array}$ & Entrepreneurial bricolage & $\begin{array}{l}\text { Variations in the degree to which firms engage in bricolage behaviors can provide a } \\
\text { broadly applicable explanation of innovativeness under resource constraints by } \\
\text { new firms }\end{array}$ \\
\hline
\end{tabular}


only find obstacles (Cunha et al., 2014). When confronted with resource scarcity, individuals can become more creative (Mullainathan \& Shafir, 2013). As a counterproductive side effect, resource scarcity can also lead to a tunnel effect, in which individuals neglect factors that might be important for innovation (Mullainathan \& Shafir, 2013). These two effects might explain why resource scarcity facilitates innovation in some situations, but can lead to failure in others.

Second, since acquiring and creating new resources is out of reach in resource-constrained environments, bricolage requires the ability to making do with what resources are available. Bricoleurs are able to 'make do' with cheap and free resources that others regard as useless and recombine them for new purposes (Baker \& Nelson, 2005). Such 'making do' is about applying combinations of the resources at hand to new problems and opportunities (Baker \& Nelson, 2005). Of course, this can create solutions that are neither perfect nor elegant (LeviStrauss, 1966). Nevertheless, such solutions might assist organizations when they face market uncertainties and when they want to test new products and services rather quickly.

Making do with what is available is regarded as a type of stop-gap tactic that leads to imperfect ('good-enough') solutions. When a firm adopts extremely high standards of 'good enough' solutions under severe resource constraints, bricolage can even trigger radical innovation (Levi-Strauss, 1966). 'Good enough' solutions might initially attract less demanding customers, but once these solutions become mature, they can disrupt the existing markets through the formation of a new value constellation (Christensen, 2013). Such 'good enough' solutions often occur through a leveraging process; for example, the recombination of existing resources. External resources (such as customers' knowledge and skills) are used to fill gaps and to enhance or add value to existing resources.

Third, bricolage requires the ability to improvise. Improvisation can be viewed as a tactic of the organization to mobilize and combine resources in a novel way (Weick, 1993). It includes compensation approaches to close the gap caused by resource scarcity by utilizing other, existing resources that compensate for the missing resources (Rosenzweig et al., 2016). Bricoleurs are seen as thinkers who are able to improve, imagine, combine, and search for new, unexpected resources (Miettinen \& Virkkunen, 2005). Improvising does not occur randomly, and instead requires an accumulation of knowledge and experiences (Duymedjian \& Rüling, 2010) combined with intuition, creativity, and problem-solving. In resource-constrained environments, innovators must cleverly use existing resources and available information. The current situation - the here and now - is more heightened and used to inform innovation decisions than predictions of future developments.

Improvisation requires rigorous trial-and-error experimentation, which will lead to the gradual accumulation of knowledge and skills through learning from failures and successes of different experiments (Duymedjian \& Rüling, 2010). A decision about whether an organization should invest in improvisation through trial-and-error experimentation should not be based on expected returns, budgets, and schedules. Instead, the decision should be made by considering the affordability of the loss (Sarasvathy \& Dew, 2008). Organizations implementing bricolage capabilities reduce their risks by understanding what they can afford to lose (Coviello \& Joseph, 2012). However, affordable loss also suggests that highly creative but risky innovation opportunities may be lost as innovators seek to focus on and integrate synergistic resources (Blauth, Mauer, \& Brettel, 2014). This not only leads to incremental innovation, but sometimes even to radical and discontinuous innovations.

Fourth and finally, bricolage requires the ability to network with external partners for better coping with resource constraints (Perry, Chandler, \& Markova, 2012). Gaining access to external resources is considered a key driver for networking, as resources residing outside the organization enable novel resource combinations, complex problem solving, reduced development times and costs, and faster commercialization and diffusion of the innovation (Aarikka-Stenroos, Sandberg, \& Lehtimäki, 2014; Tether \& Tajar, 2008). External resources can be accessed in two main ways: by acquiring resources through market transactions, or by mobilizing resources through partnering and collaborating with external organizations (Coviello \& Cox, 2006). Gaining access to resources by other network actors necessitates that the bricoleur can offer something in return: either monetary compensation or some other resources that are valuable to the other actors. Naturally, such market transactions are unlikely in resource-constrained environments. Thus, a bricoleur's network, partnering, and collaboration abilities are often about mobilizing external resources.

Such a networking capability is often directed toward the customer, which particularly aligns with the ideas of co-creation of innovation with customers (Witell, Kristensson, Gustafsson, \& Löfgren, 2011). Cocreation of innovation often appears in-situ, which enables customers to utilize existing resources in an efficient manner consistent with the bricolage concept (Edvardsson, Kristensson, Magnusson, \& Sundström, 2012). Bricoleurs are highly cognizant of their existing resources, which increases the likelihood that they will understand the need for alignment with external resources to support innovation. They can deliberately build networking capability such as mobilizing and engaging customers to accumulate their resources and be open-minded to customer ideas.

While each of these four bricolage capabilities are mandatory, they are not sufficient to achieve growth (Baker \& Nelson, 2005). Fisher (2012) suggests that applying different bricolage approaches in parallel may result in a bricolage "trap" that restricts growth and innovation success. Parallel bricolage means that organizations deploy the bricolage capabilities to multiple ongoing service innovation projects and across the entire NSD processes. It has been argued that a selective bricolage approach can break through resource constraints while also establishing a base for firm growth. Instead of deploying bricolage capabilities consistently and repeatedly across multiple service innovation projects and entire NSD processes, organizations should use it selectively (Baker \& Nelson, 2005).

\section{Applying the bricolage concept to service innovation}

\subsection{Theory development and empirical illustrations}

Although theories on bricolage and service innovation appear to share a similar logic with respect to recombining resources in novel ways, bricolage remains a relatively underexplored area in service innovation research (Storey et al., 2016). An interesting exception is a study on the impact of bricolage capabilities on interactive and supportive service innovation (Salunke et al., 2013). That study found that bricolage capabilities increase the level of interactive and supportive service innovation, which leads to a sustainable competitive advantage.

In order to advance service innovation research from a bricolage perspective, we need to provide theoretical explanations, empirically test these explanations, and extend and/or revise generalized explanations (Bagozzi, 1980; Bass \& Wind, 1995). The process starts with theory development. At this stage, it is important to carefully delineate the theoretical constructs of bricolage and transfer them into propositions of how bricolage capabilities influence service innovation outcomes. Service innovation outcomes are non-financial (for example, customer satisfaction, loyalty) and financial indicators (profit, revenues, etc.). In our discussion below, we do not distinguish between such individual outcomes, but instead highlight the influence of bricolage capabilities on service innovation more generally.

In the present study, we reflect and provide theoretical explanations on how the concept of bricolage and the four specific bricolage capabilities are manifested in practice. The purpose is not to use empirical data for deriving conclusions, but to illustrate what resource scarcity and bricolage capabilities may mean in practice. This helped us identify potential areas for further research. For empirical illustrations, we selected five cases to show how bricolage capabilities influence service innovation outcomes. We selected these cases to cover different sectors and 
types of organizations, as well as a variety of resource-constrained environments:

1. SOIL (Sustainable Organic Livelihood) is a non-profit organization that develops new services to improve sanitary conditions in urban slums. SOIL and its partners in the business environment lack the resources to devise promising service innovations to improve sanitary conditions. Furthermore, people living in urban slums lack the financial resources to afford an improved sanitation service. Therefore, SOIL represents an innovation context in which research scarcity is evident in the focal organization, customers, and the surrounding infrastructure.

2. HomeInstead is a public organization that provides customized elderly care services. Homelnstead faces internal resource constraints in terms of limited time, human resources, and financial resources to provide elderly care services.

3. Bosch Lab is a development unit of Bosch that has substantial experiences as an automotive supplier throughout the R\&D, production, and service of car components. Bosch Lab lacks adequate internal resources to explore new service opportunities surrounding digitization and IoT technologies. In addition, since these emerging technologies are still in a state of flux and the actual service opportunities are still uncertain, the necessary resources are scarce in the entire automotive industry.

4. Ericsson, a global actor in the telecommunications industry, has recently launched "garage projects", in which employees and external actors on purpose are confronted with resource scarce environments similar to working as a startup company. Ericsson expected that such purposefully created resource-constrained environments (garage projects) would facilitate new services that would not have resulted from its traditional innovation approaches.

5. Cemex is a Mexican cement manufacturer that provides social housing services to families living close to the poverty line. These families have limited financial resources to pay for the social housing services and competences to actively participate in the house construction. In addition, Cemex traditionally sells cement to middle- and high-income families, but has limited knowledge about how to serve families living close to the poverty line.

Details of the resource constraints and bricolage capabilities for each case are summarized in Table 3. Overall, while all five cases face various resource constraints, they nevertheless attempt to innovate new services. Instead of formalizing the NSD process, these organizations deploy a range of bricolage capabilities in response to these constraints. In the following, we discuss how bricolage capabilities influence the service innovation outcomes and summarize our discussion as research propositions illustrated in a conceptual framework.

\subsection{Bricolage capabilities and service innovation outcomes}

It has been argued that actively addressing resource scarcity influences the deployment of other bricolage capabilities in a way that enables firms to seize sustainable competitive advantages where competitors may only find obstacles (Cunha et al., 2014). Resourceconstrained environments might heighten individual creativity (Mullainathan \& Shafir, 2013), which would bring ideas to practice. In case of SOIL, we observed that the founders recognized that people living in urban slums simply cannot afford a traditional pit latrine. The dense housing and regular flooding occurring in slums restricts the installation of such latrines. Even people with money and space face constraints in terms of inadequate material and components to build proper sanitation facilities (toilets). Many organizations lacked the creativity required to come up with alternative sanitation solutions, but SOIL created a mindset to tackle social problem on sanitation and continually aimed to improve the social value creation. This enhanced creativity levels across the organization, leading to a new sanitation service that customers really like and are very happy to pay for. By actively addressing resource scarcity, SOIL strengthens its ability to make do with what is available, to improvise in the (re)combination of resources, and to network with external partners. These capabilities lead to a sanitation service, which ensured customer satisfaction and achieved the expected revenues.

The Ericsson case further substantiates the positive influence that actively addressing resource constraints has on further bricolage capabilities. In Ericsson's garage projects, employees were deliberately confronted with resource-constrained environments. For a limited time, employees work as new start-up firms through the lean-start-up approach. Employees became highly motivated to circumnavigate the resource constraints and were inspired by the start-up challenge, thereby heightening their creativity. Such an enhanced creativity strengthened other bricolage capabilities. The other cases - HomeInstead and Bosch Lab - illustrate the positive influence of resource scarcity on creativity. Thus, we propose that:

Table 3

Bricolage capabilities and service innovation outcomes in the selected cases.

\begin{tabular}{|c|c|c|c|c|c|}
\hline & Bosch Lab & Cemex & Ericsson & HomeInstead & SOIL \\
\hline $\begin{array}{l}\text { Addressing } \\
\text { resource } \\
\text { scarcity } \\
\text { actively }\end{array}$ & $\begin{array}{l}\text { Creating a context of resource } \\
\text { scarcity increases the } \\
\text { creativity of the innovation } \\
\text { teams. }\end{array}$ & $\begin{array}{l}\text { Encouraging innovation } \\
\text { managers to live in informal } \\
\text { settlements in order to increase } \\
\text { the level of creativity. }\end{array}$ & $\begin{array}{l}\text { Creating a context of } \\
\text { resource scarcity, increases } \\
\text { creativity and motivation of } \\
\text { the innovation teams. }\end{array}$ & $\begin{array}{l}\text { Caregivers are permanently } \\
\text { confronted by resource } \\
\text { scarcity and convert this into } \\
\text { new ideas for improving } \\
\text { health care services. }\end{array}$ & $\begin{array}{l}\text { Employees face severe } \\
\text { resource constraints in } \\
\text { low-income markets, but still } \\
\text { come up with interesting } \\
\text { services for solving sanitation } \\
\text { problems. }\end{array}$ \\
\hline $\begin{array}{l}\text { Making do } \\
\text { with what } \\
\text { is } \\
\text { available }\end{array}$ & $\begin{array}{l}\text { Good-enough solutions } \\
\text { originating from making do } \\
\text { with what is had at hand, were } \\
\text { not always accepted by } \\
\text { more-demanding customers. }\end{array}$ & $\begin{array}{l}\text { Ability to make do with what is } \\
\text { at hand led to simple house } \\
\text { construction services, which, in } \\
\text { turn, were sufficient to attract } \\
\text { customers. }\end{array}$ & $\begin{array}{l}\text { Ability to make do with } \\
\text { what it had at hand led to } \\
\text { basic IoT solutions. These } \\
\text { are used as demonstrations } \\
\text { of what is possible. }\end{array}$ & $\begin{array}{l}\text { Caregivers used the available } \\
\text { resources to come up with a } \\
\text { good-enough service, which } \\
\text { was tested and } \\
\text { commercialized relatively } \\
\text { quickly. }\end{array}$ & $\begin{array}{l}\text { Ability to make do with what is } \\
\text { at hand led to relative simple } \\
\text { sanitation services, which in } \\
\text { turn attract many customers. }\end{array}$ \\
\hline $\begin{array}{l}\text { Improvising } \\
\text { when } \\
\text { combining } \\
\text { resources }\end{array}$ & $\begin{array}{l}\text { Improvising led to various } \\
\text { improvement in the digital } \\
\text { services, which increased the } \\
\text { likelihood of commercial } \\
\text { success. }\end{array}$ & $\begin{array}{l}\text { Ability to improvise led to } \\
\text { various improvements in the } \\
\text { housing construction services, } \\
\text { which made these services } \\
\text { commercially more successful. }\end{array}$ & $\begin{array}{l}\text { Ericsson's ability to } \\
\text { improvise led to various } \\
\text { adaptations of the services, } \\
\text { but they have not yet been } \\
\text { introduced on the market. }\end{array}$ & $\begin{array}{l}\text { Caregivers improvised to } \\
\text { circumnavigate obstacles on } \\
\text { integrating neighbors and } \\
\text { family members leading to a } \\
\text { new health care service. }\end{array}$ & $\begin{array}{l}\text { Ability to improvise led to } \\
\text { various adaptations of the } \\
\text { services, which increased } \\
\text { customer satisfaction. }\end{array}$ \\
\hline $\begin{array}{l}\text { Networking } \\
\text { with } \\
\text { external } \\
\text { partners }\end{array}$ & $\begin{array}{l}\text { Collaborating with external } \\
\text { partners can delay the } \\
\text { innovation processes, leading } \\
\text { to late market launches } \\
\text { limiting the commercial }\end{array}$ & $\begin{array}{l}\text { Collaboration with customers } \\
\text { led sometimes to little realistic } \\
\text { customer expectations, which } \\
\text { could not inform new service } \\
\text { ideas. }\end{array}$ & $\begin{array}{l}\text { Collaborating with external } \\
\text { partners have provided } \\
\text { additional knowledge and } \\
\text { skills with positive effects } \\
\text { on the outcome. }\end{array}$ & $\begin{array}{l}\text { Networking with family } \\
\text { members and neighbors led } \\
\text { to novel self-help groups. }\end{array}$ & $\begin{array}{l}\text { Networking with women's } \\
\text { groups and carpenters reduced } \\
\text { the service costs, which in turn } \\
\text { attracted new customers. }\end{array}$ \\
\hline
\end{tabular}
successes. 
Proposition 1. Addressing resource constraints actively is positively associated with strengthening bricolage capabilities of making do, improvising and networking.

Capabilities for making do with what organizations have at hand assist organizations when they face market uncertainties, and when they want to test new products and services somewhat quickly. In the case of HomeInstead, caregivers started working with family members, friends, and neighbors that were "at hand". Of course, these people had limited experience with participating actively in the value creation of elderly care services. Caregivers advised them, which led to a 'goodenough' solution for improving the elderly care services. This solution can be further tested and developed in order to turn the initial 'good enough' solution into a high-quality care service.

While the evidence of HomeInstead suggests a positive impact, the Bosch Lab case shows that making do with resources "at hand" might lead to solutions that do not become commercial successes. In the Bosch Lab, employees use the technological resources at hand for new IoT services. They immediately designed new services, which took advantage of these technological resources and tested them. These were good enough service concepts that attracted internal attention and a few customers were invited to participate in further developing and launching the services. It was recognized later that these customers were relatively undemanding in terms of the service innovation. Thus, the new service did not appeal to larger markets and more demanding customers. The Bosch Lab case illustrates that capabilities for making do with what organizations have at hand can lead to good enough solutions, which in some respects attract rather undemanding customers (Garud \& Karnøe, 2003; Senyard, Baker, \& Davidsson, 2009). Later, organizations may face difficulties growing such solutions because they are not appealing to a larger set of customers and may be especially unappealing to highly demanding consumers (Senyard et al., 2009).

Similarly, SOIL initially benefited from focusing on central aspects when it innovated mobile sanitation services for festivals, events, and construction sites. This tactic saved time and increased the effectiveness in the development stage. However, placing special attention on certain service elements did not really save time and eliminations actually jeopardized service revenues. SOIL initially paid attention to the treatment (composting) process, but eliminated the customer service activities in order to maintain a relationship with the compost customers. Without these activities, SOIL faced difficulties retaining the existing compost customers and the corresponding revenues.

These examples illustrate how making do eases innovation tasks by allowing attention to focus on specific and central areas, saving time and enhancing effectiveness, but how it can also delay the innovation process and reduce service quality and ultimately service revenues (Eisenhardt, 1989; Rosenzweig et al., 2016). Making do is about using with what the organization has at hand to develop good enough solutions, which can be tested quickly in the market. It seems plausible that when the available resources are relatively well aligned with the needs or demand level of the market (as in the HomeInstead case), this capability leads to positive innovation outcomes. However, when the demands of the market differ considerably from the resources available, as in the Bosch Lab case, the outcome may be negative. Thus, on the basis of prior research, we established two competing propositions:

Proposition 2a. Capabilities for making do with what organizations have at hand are positively associated with service innovation outcomes.

Proposition 2b. Capabilities for making do with what organizations have at hand are negatively associated with service innovation outcomes.

In our illustrative cases, improvising was observed in the development and launch stages of service innovation. Improvisation in terms of intuition, imagination, and creativity leads to novel solutions, which are appreciated by customers (Duymedjian \& Rüling, 2010). In the HomeInstead case, various types of improvisation were observed. To improvise new value creation processes after elderly patients get home from the hospitals, caregivers started to engage family members and neighbors in active roles, see also McColl-Kennedy, Hogan, Witell, and Snyder (2017). Neighbors sometimes organized shopping, but occasionally bought the wrong food. Family members and elderly patients themselves were not confident when it came to helping patients take a shower or go to the bathroom. Caregivers later utilized this improvisation experience in a novel service element, called self-help groups. These self-help groups consisted of people who used their own experience about the first days at home from the hospital for other people facing a similar situation. Such self-help groups became important actors in the value creation process and improved the value co-creation process.

Trial-and-error experimentation as a part of improvisation capabilities is assumed to have a positive impact on service innovation outcomes, emerging when organizations pay attention to an affordable loss rather than expected returns (Sarasvathy \& Dew, 2008). This example highlights the importance of improvisation, which leads us to propose:

Proposition 3. Improvising capabilities are positively associated with service innovation outcomes.

Finally, networking capability comprising mobilizing and collaborating with external partners for better coping with resource constraints has been argued to have a positive impact on service innovation outcomes (e.g., Aarikka-Stenroos et al., 2014). Due to resource constraints, SOIL was highly cognizant of its resources and could therefore understand what kind of external resources were needed. SOIL mobilized carpenters to address scarcity among their resources to produce toilets as part of the sanitation service. The organization was flexible in terms of switching among carpenters and innovative in terms of utilizing these resources as a production input. SOIL recognized that these carpenters did not have any space to carry out the construction work, so it organized space close to its offices, which served as a workshop. SOIL was also flexible and innovative when it came to networking with potential users to really test the durability of the toilets and quality of the sanitation services. They initially lacked access to users who would be interested in testing these sanitation services, so they asked their employees and their relatives to use the sanitation services. SOIL considered them as 'test laboratories' that provided assistance in changing the product design.

In contrast, Bosch Lab faced resource constraints that made them not reach the expected service innovation outcomes. Instead of being aware of available resources and understanding what external resources that were available, Bosch Lab was relatively unmindful about what external resources could be beneficial. It was mobilizing several external partners (IT experts, consulting firms, technology providers, etc.) in order to gain access to various resources. However, these various resources did not facilitate new (re)combination of resources. Thus, insufficient understanding on the resources needed from external partners impaired the impact of networking capability on service innovation outcomes.

In a similar vein, the cases illustrate both positive and negative effects of networking with customers. Collaborating with customers was highlighted as a key success factor (de Brentani, 2001; Edvardsson et al., 2012). HomeInstead's caregivers recognized resource constraints for providing health care services to elderly people who had just returned home from hospital visits. Caregivers gained valuable knowledge when they observed the daily routines of elderly people. Through these observations, they learned how to integrate family members into the health care services. Integrating family members made elderly people more communicative about their expectation and needs, which in turn improved service quality.

In contrast, Cemex reached out and engaged in dialogue to collaborate with families that were potential customers in social housing programs. Interested families faced educational constraints (such as illiteracy, lack of construction skills, preoccupation with cultural habits) 
and had difficulty expressing their needs and preferences. This in-depth dialogue was not able to overcome the constraints and often led to unrealistic expectations, such as houses being large residences with two floors like those they had seen in their favorite telenovelas. The dialogues with customers led to unrealistic expectations that the social housing program could not match. Customers were dissatisfied and rejected having to pay for the housing services. Consequently, networking was observed to not have improved the service innovation outcomes. Considering these and similar arguments, we again put forth two competing propositions:

Proposition 4a. Networking capabilities are positively associated with service innovation outcomes.

Proposition 4b. Networking capabilities are negatively associated with service innovation outcomes.

\subsection{Conceptual model on bricolage capabilities and service innovation outcomes}

Our four propositions inform a conceptual model on bricolage capabilities and service innovation. As illustrated in Fig. 1, addressing resource constraints actively does not have a direct positive effect on the service innovation outcomes. Instead, it has an indirect effect, in which bricolage capabilities such as making do, improvising, and networking mediate its influence on service innovation outcomes. Bricolage capabilities such as making do, improvising, and networking directly influence service innovation outcomes. Improvising is proposed to have a positive influence, whereas we have identified competing propositions on how making do and networking capabilities influence service innovation outcomes. In addition, we have identified several potential contingencies that are believed to influence the relationships between bricolage capabilities and service innovation outcomes.

The difference between whether the influence of bricolage capabilities is positive or negative might depend on the bricolage approach. The negative influence of capabilities on service innovation outcomes could occur if companies deploy parallel bricolage. Following Fisher (2012), the four bricolage capabilities can only influence the service innovation outcomes positively if companies follow a selective bricolage approach.
Besides the bricolage approach ( parallel versus selective), our conceptual model should consider the actual type of service innovation, type of resource constraints, and the actual stage in the NSD process. Our cases cover different types of services, but the question of how the type of service moderates the causal relationships underlying our propositions remains open. Thus, we recommend that our propositions should be tested for different types of services. A similar argument applies to the resource constraints. Different types of resource constraints could also moderate the relationships between bricolage capabilities and service innovation outcomes. Our propositions can be tested for constraints originating from customers, the business environments, or the organization itself. Finally, service innovation outcomes could be further differentiated according to the service innovation process (for example, design, analysis, development, and full launch). In the design stage, outcomes would be the number of new service ideas, whereas outcomes of the launch stage would be financial outcomes such as revenues and profitability as well as non-financial outcomes such as customer satisfaction and loyalty. It would be interesting to explore whether the proposed influence of bricolage capabilities differs throughout the different service innovation stages.

\section{Conclusions}

In the present research, we shift the attention of service innovation from resource-rich environments to resource-constrained environments. In addition, we go beyond the formalization of NSD processes and explore how bricolage capabilities influence service innovation outcomes. Bricolage is not expected to substitute the formalization, but rather to supplement it. Further, we extend the bricolage concept, which has been mostly applied to product and technology innovation, toward service innovation. Finally, our discussion leads to four testable propositions, which can guide and be tested by further research.

\subsection{Theoretical implications}

In this article, we have argued to depart from the common assumption that formalizing the NSD process is the only way to improve service innovation outcomes. We suggest that more research in resourceconstrained environments is necessary, both to further advance theory

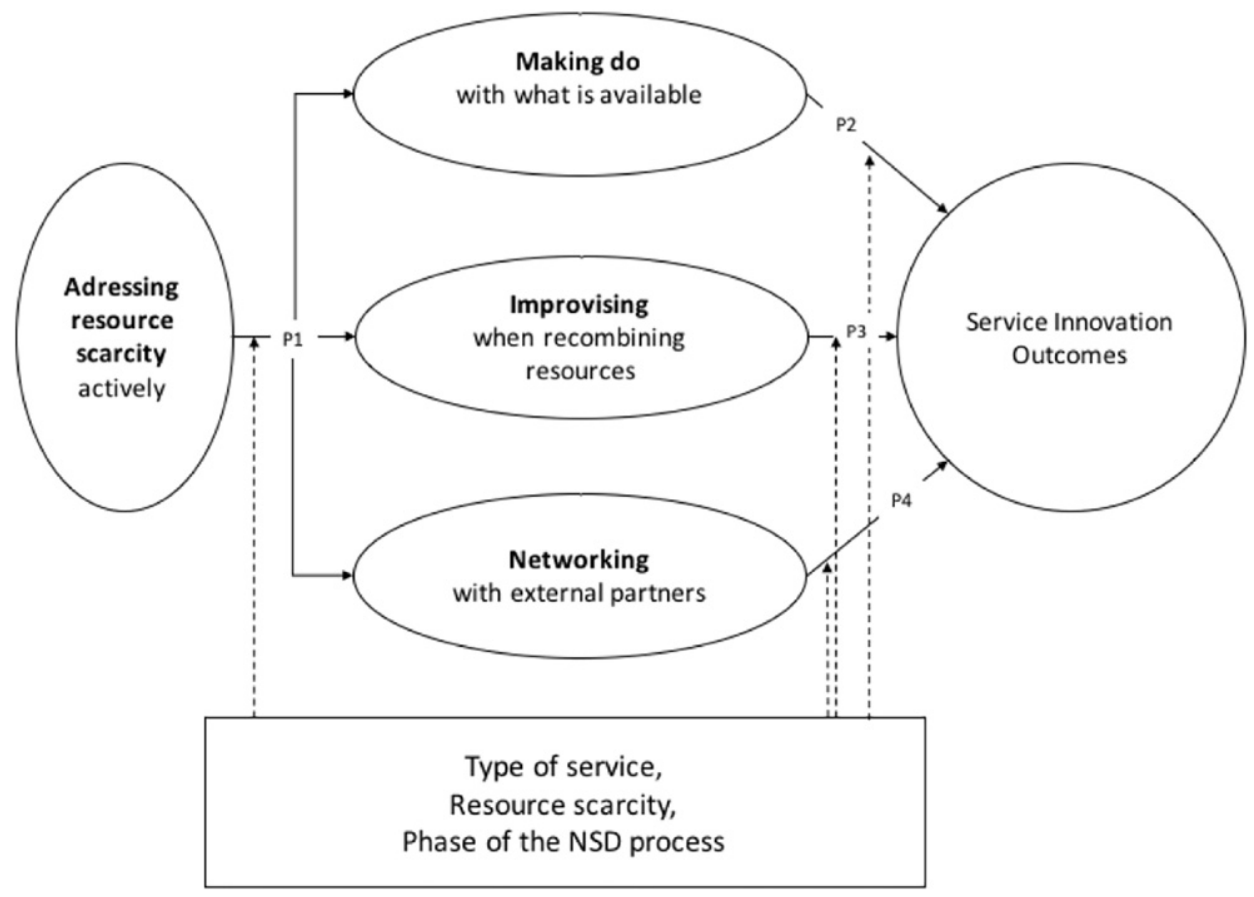

Fig. 1. Conceptual model with four propositions. 
development on service innovation as well as to maintain its managerial relevance. We advanced service innovation and the bricolage concept through theory development and empirical illustrations. In order to test our four propositions, further research should continue with qualitative and quantitative studies on service innovation in resourceconstrained environments. Researchers should select the relevant empirical context, conceptualize and operationalize the necessary constructs, and consider various adaptations of the propositions.

Our five case illustrations can inform further research on relevant empirical contexts. Services such as SOIL's sanitation service targeting low-income segments - in other words, the base-of-the pyramid markets - have become a service research priority (e.g., Fisk et al., 2016; Gebauer \& Reynoso, 2013). Such markets are naturally resourceconstrained environments for any non-profit organization and social business, but service innovation plays a vital role in improving the well-being of consumers (Anderson \& Ostrom, 2015). This empirical context resonates with the call to embed research on social innovation into service innovation literature (Rubalcaba, Michel, Sundbo, Brown, \& Reynoso, 2012). The public sector, specifically health care, is another promising empirical context. Previous research has investigated service innovation in this context (Elg, Engström, Witell, \& Poksinska, 2012), but bricolage as a response to resource constraints in healthcare could advance service research even further (Fuglsang \& Sørensen, 2011). Finally, service innovation emerging in product companies trying to explore new technological opportunities represents another interesting empirical context. Traditional product companies lack sufficient technology resources, are uncertain how these technologies lead to new business opportunities, and cannot assess the actual risks. Thus, bricolage capabilities might help them to deal with these constraints.

In the next step, research should further develop and describe the theoretical constructs. While appropriate scales and constructs already exist for service innovation outcomes, the four bricolage capabilities require further development of new and refinement of existing scales. Bricolage has previously been operationalized through three items such as (i) the ability to combine resources in ways that challenge conventional business practices, (ii) to combine resources in a manner that extracts value from under-utilized resources, and (iii) to deploy resources in ways that allow for innovative solutions (Salunke et al., 2013). We suggest that, instead of operationalizing bricolage as a single construct, bricolage should be higher-order constructs, including multiple first-order constructs. Bricolage capabilities should be conceptualized and operationalized as multiple first-order constructs for further qualitative and quantitative research.

We have developed testable propositions for further research on service innovation in resource-constrained environments. It has been argued that the capability to actively address resource constraints and the improvising capability can improve service innovation outcomes. Further research should look into the competences and skills necessary for developing these capabilities. It would be interesting to understand what competences and skills are necessary alternatively limit organizations and individuals to actively address resource constraints. Similarly, research should gain a deeper understanding of the necessary competences and skills for developing improvising capability in the service innovation process.

Interestingly, capabilities such as networking and making do with the resources at hand are core constructs in the bricolage and service innovation literature. However, we suggest that these capabilities do not automatically improve service innovation outcomes. While our empirical illustrations are not generalizable, further research should explore the circumstances under which these capabilities would improve service innovation outcomes. Whether networking capability and/or capability to make do with the resources at hand have a positive and/or negative influence on service innovation might depend on the bricolage approach (parallel versus selective).

Similarly, research should differentiate among various types of resource constraints and explore whether a negative impact only occurs for specific constraints and/or across all types of constraints. For example, networking capability (collaborating with customers) might have only a negative influence on the service innovation outcome when the customers lack the necessary resources (competences and skills) to clearly articulate their needs. Instead of looking at networking capability from a generic perspective, it might be interesting to look further into different types of networking, such as collaborating with customers and other actors. This would be consistent with the argument that (re)combinations of resources do not arise solely through the resources owned by the service provider and the customers, but are orchestrated through interactions among actors across the service system (Srivastava \& Shainesh, 2015).

\subsection{Managerial implications}

Managers should be aware that bricolage capabilities might be a promising alternative to a strong formalization of the NSD process. Bricolage capabilities spark creativity and infuse new service ideas into the organization. Organizations that try to implement bricolage as an alternative approach to NSD can visualize the four bricolage capabilities we have identified, and assess their current strengths and weaknesses. Our findings enable managers to take a close look at their existing bricolage capabilities and make strategic decisions for capability development. Practitioners can use our framework as a guideline for bricolage and service innovation. While our discussion of bricolage capabilities sounds rational, organizations should understand that they differ from common practices for service innovation. For example, we suggest that managers should take up ideas such Ericsson's Garage, which tries to artificially create the prerequisites for bricolage in service innovation, even if there would be more resources available.

\section{References}

Aarikka-Stenroos, L., Sandberg, B., \& Lehtimäki, T. (2014). Networks for the commercialization of innovations: A review of how divergent network actors contribute. Industrial Marketing Management, 43(3), 365-381.

Andersen, O. J. (2008). A bottom-up perspective on innovations: Mobilizing knowledge and social capital through innovative processes of bricolage. Administration and Society, 40(1), 54-78.

Anderson, L., \& Ostrom, A. L. (2015). Transformative service research advancing our knowledge about service and well-being. Journal of Service Research, 18(3), 243-249. Bagozzi, R. P. (1980). Causal models in marketing. New York: Wiley.

Baker, T. (2007). Resources in play: Bricolage in the toy store(y). Journal of Business Venturing, 22(5), 694-711.

Baker, T., \& Nelson, R. E. (2005). Creating something from nothing: Resource construction through entrepreneurial bricolage. Administrative Science Quarterly, 50(3), 329-366.

Barrett, A., Bergin, A., FitzGerald, J., Lambert, D., McCoy, D., Morgenroth, E., ... Studnicka, Z. (2015). Scoping the possible economic implications of Brexit on Ireland. ESRI Research Series, 48.

Bass, F. M., \& Wind, J. (1995). Introduction to the special issue: Empirical generalizations in marketing. Marketing Science, 14(3), G1-G5.

Biemans, W. G., Griffin, A., \& Moenaert, R. K. (2015). New service development: How the field developed, its current status and recommendations for moving the field forward. Journal of Product Innovation Management, 33(4), 382-397.

Blauth, M., Mauer, R., \& Brettel, M. (2014). Fostering creativity in new product development through entrepreneurial decision making. Creativity and Innovation Management, 23(4), 495-509.

de Brentani, U. (2001). Innovative versus incremental new business services: Different keys for achieving success. Journal of Product Innovation Management, 18(3), 169-187.

Christensen, C. (2013). The innovator's dilemma: When new technologies cause great firms to fail. Harvard Business Review Press.

Ciborra, C. U. (1996). The platform organization: Recombining strategies, structures, and surprises. Organization Science, 7(2), 103-118.

Cooper, R. G., \& de Brentani, U. (1991). New industrial financial services: What distinguishes the winners. Journal of Product Innovation Management, 8(2), 75-90.

Coviello, N. E., \& Cox, M. P. (2006). The resource dynamics of international new venture networks. Journal of International Entrepreneurship, 4(2-3), 113-132.

Coviello, N. E., \& Joseph, R. M. (2012). Creating major innovations with customers: Insights from small and young technology firms. Journal of Marketing, 76(6), 87-104.

Cunha, R. A., Oliveira, P., Rosado, P., \& Habib, N. (2014). Product innovation in resourcepoor environments: Three research streams. Journal of Product Innovation Management, 31(2), 202-210.

Desa, G. (2012). Resource mobilization in international social entrepreneurship: Bricolage as a mechanism of institutional transformation. Entrepreneurship: Theory and Practice, 36(4), 727-751. 
Duymedjian, R., \& Rüling, C. C. (2010). Towards a foundation of bricolage in organization and management theory. Organization Studies, 31(2), 133-151.

Edvardsson, B., Kristensson, P., Magnusson, P., \& Sundström, E. (2012). Customer integration within service development - A review of methods and an analysis of insitu and exsitu contributions. Technovation, 32(7), 419-429.

Edvardsson, B., Meiren, T., Schäfer, A., \& Witell, L. (2013). Having a strategy for new service development-does it really matter? Journal of Service Management, 24(1), 25-44.

Eisenhardt, K. M. (1989). Making fast strategic decisions in high-velocity environments. Academy of Management Journal, 32(3), 543-576.

Elg, M., Engström, J., Witell, L., \& Poksinska, B. (2012). Co-creation and learning in healthcare service development. Journal of Service Management, 23(3), 328-343.

Engelen, E., Erturk, I., Froud, J., Leaver, A., \& Williams, K. (2010). Reconceptualizing financial innovation: Frame, conjuncture and bricolage. Economy and Society, 39(1), 33-63.

Essén, A. (2009). The emergence of technology-based service systems a case study of a telehealth project in Sweden. Journal of Service Management, 20(1), 98-121.

Ferdows, K. (2006). POM forum: Transfer of changing production know-how. Production and Operations Management, 15(1), 1-9.

Fisher, G. (2012). Effectuation, causation, and bricolage: A behavioral comparison of emerging theories in entrepreneurship research. Entrepreneurship Theory and Practice, 36(5), 1019-1051.

Fisk, R. P. P., Anderson, L., Bowen, D. E., Gruber, T., Ostrom, A., Patrício, L., ... Sebastiani, R. (2016). Billions of impoverished people deserve to be better served: A call to action for the service research community. Journal of Service Management, 27(1), 43-55.

Froehle, C. M., Roth, A. V., Chase, R. B., \& Voss, C. A. (2000). Antecedents of new service development effectiveness an exploratory examination of strategic operations choices. Journal of Service Research, 3(1), 3-17.

Fuglsang, L. (2010). Bricolage and invisible innovation in public service innovation. Journal of Innovation Economics \& Management, 3(1), 67-87.

Fuglsang, L., \& Sørensen, F. (2011). The balance between bricolage and innovation: Management dilemmas in sustainable public innovation. The Service Industries Journal, 31(4), 581-595.

Gallouj, F., \& Weinstein, O. (1997). Innovation in services. Research Policy, 26(4), 537-556.

Garud, R., \& Karnøe, P. (2003). Bricolage versus breakthrough: Distributed and embedded agency in technology entrepreneurship. Research Policy, 32(2), 277-300.

Gatignon, H., \& Xuereb, J. M. (1997). Strategic orientation of the firm and new product performance. Journal of Marketing Research, 34(1), 77-90.

Gebauer, H., Gustafsson, A., \& Witell, L. (2011). Competitive advantage through service differentiation by manufacturing companies. Journal of Business Research, 64(12), 1270-1280.

Gebauer, H., \& Reynoso, J. (2013). An agenda for service research at the base of the pyramid. Journal of Service Management, 24(5), 482-502.

Gupta, A. K., Smith, K. G., \& Shalley, C. E. (2006). The interplay between exploration and exploitation. Academy of Management Journal, 49(4), 693-706.

Halme, M. Lindeman, S. \& Linna, P. (2012). Innovation for inclusive business: Intrapreneurial bricolage in multinational corporations. Journal of Management Studies, 49(4), 743-784.

Hirschman, A. O. (1958). The strategy of economic development. New Haven: Yale University Press.

Johne, A., \& Storey, C. (1998). New service development: A review of the literature and annotated bibliography. European Journal of Marketing, 32(3/4), 184-251.

Levi-Strauss, C. (1966). The savage mind. Chicago: University of Chicago Press.

Leybourne, S., \& Sadler-Smith, E. (2006). The role of intuition and improvisation in project management. International Journal of Project Management, 24(6), 483-492.

Lindblom, C. E. (1959). The science of "muddling through". Public Administration Review, 19(2), 79-88.

Linna, P. (2013). Bricolage as a means of innovating in a resource-scarce environment: A study of innovator-entrepreneurs at the BOP. Journal of Developmental Entrepreneurship, 18(03), 1350015.

Lusch, R. F., \& Nambisan, S. (2015). Service innovation: A service-dominant logic perspective. MIS Quarterly, 39(1), 155-175.

Lusch, R. F., Vargo, S. L., \& O'Brien, M. (2007). Competing through service: Insights from service-dominant logic. Journal of R, 83(1), 5-18.

McColl-Kennedy, J. R., Hogan, S. J., Witell, L., \& Snyder, H. (2017). Cocreative customer practices: Effects of health care customer value cocreation practices on well-being. Journal of Business Research, 70(1), 55-66.

Melton, H., \& Hartline, M. D. (2015). Customer and employee co-creation of radical service innovations. Journal of Services Marketing, 29(2), 112-123.

Michel, S., Brown, S. W., \& Gallan, A. S. (2008). An expanded and strategic view of discontinuous innovations: Deploying a service-dominant logic. Journal of the Academy of Marketing Science, 36(1), 54-66.

Miettinen, R., \& Virkkunen, J. (2005). Epistemic objects, artefacts and organizational change. Organization, 12(3), 437-456.
Mullainathan, S., \& Shafir, E. (2013). Scarcity: Why having too little means so much. New York: Macmillan.

Ostrom, A. L., Parasuraman, A., Bowen, D. E., Patricio, L., Voss, C. A., \& Lemon, K. (2015). Service research priorities in a rapidly changing context. Journal of Service Research, 18(2), 127-159.

Papastathopoulou, P., \& Hultink, E. J. (2012). New service development: An analysis of 27 years of research. Journal of Product Innovation Management, 29(5), 705-714.

Perry, J. T., Chandler, G. N., \& Markova, G. (2012). Entrepreneurial effectuation: A review and suggestions for future research. Entrepreneurship Theory and Practice, 36(4), 837-861.

Ray, G., Barney, J. B., \& Muhanna, W. A. (2004). Capabilities, business processes, and competitive advantage: Choosing the dependent variable in empirical tests of the resource-based view. Strategic Management Journal, 25(1), 23-37.

Rosenzweig, S., Grinstein, A., \& Ofek, E. (2016). Social network utilization and the impact of academic research in marketing. International Journal of Research in Marketing, 33(4), 818-839.

Rubalcaba, L., Michel, S., Sundbo, J., Brown, S. W., \& Reynoso, J. (2012). Shaping, organizing, and rethinking service innovation: A multidimensional framework. Journal of Service Management, 23(5), 696-715.

Salunke, S., Weerawardena, J., \& McColl-Kennedy, J. R. (2013). Competing through service innovation: The role of bricolage and entrepreneurship in project-oriented firms. Journal of Business Research, 66(8), 1085-1097.

Sarasvathy, S., \& Dew, N. (2008). Effectuation and over-trust: Debating Goel and Karri. Entrepreneurship Theory and Practice, 32(4), 727-737.

Schumpeter, J. A. (1934). The theory of economic development: An inquiry into profits, capital, credit, interest, and the business cycle. Vol. 55.Transaction publishers.

Senyard, J., Baker, T., \& Davidsson, P. (2009). Entrepreneurial bricolage: Towards systematic empirical testing. Frontiers of Entrepreneurship Research, 29(5), 5.

Senyard, J., Baker, T., Steffens, P., \& Davidsson, P. (2014). Bricolage as a path to innovativeness for resource-constrained new firms. Journal of Product Innovation Management, 31(2), 211-230.

Snyder, H., Witell, L., Gustafsson, A., Fombelle, P., \& Kristensson, P. (2016). Identifying categories of service innovation: A review and synthesis of the literature. Journal of Business Research, 69(7), 2401-2408.

Spencer, J. W., Murtha, T. P., \& Lenway, S. A. (2005). How governments matter to new industry creation. Academy of Management Review, 30(2), 321-337.

Spring, M., \& Araujo, L. (2016). Product biographies in servitization and the circular economy. Industrial Marketing Management In press 10.1016/j.indmarman.2016.07.001

Srinivas, S., \& Sutz, J. (2008). Developing countries and innovation: Searching for a new analytical approach. Technology in Society, 30(2), 129-140.

Srivastava, S. C., \& Shainesh, G. (2015). Bridging the service divide through digitally enabled service innovations: Evidence from Indian healthcare service providers. MIS Quarterly, 39(1), 245-267.

Staw, B. M. (1980). The consequences of turnover. Journal of Occupational Behavior, 1(4), 253-273.

Stevens, E., \& Dimitriadis, S. (2004). New service development through the lens of organisational learning: Evidence from longitudinal case studies. Journal of Business Research, 57(10), 1074-1084.

Storey, C., Cankurtaran, P., Papastathopoulou, P., \& Hultink, E. J. (2016). Success factors for service innovation: A meta-analysis. Journal of Product Innovation Management, 33(5), 527-548.

Storey, C., \& Easingwood, C. J. (1998). The augmented service offering: A conceptualization and study of its impact on new service success. Journal of Product Innovation Management, 15(4), 335-351.

Tether, B. S., \& Tajar, A. (2008). Beyond industry-university links: Sourcing knowledge for innovation from consultants, private research organisations and the public sciencebase. Research Policy, 37(6), 1079-1095.

Vanevenhoven, J., Winkel, D., Malewicki, D., Dougan, W. L., \& Bronson, J. (2011). Varieties of bricolage and the process of entrepreneurship. New England Journal of Entrepreneurship, 14(2), 53.

Vargo, S. L., Wieland, H., \& Akaka, M. A. (2015). Innovation through institutionalization: A service ecosystems perspective. Industrial Marketing Management, 44, 63-72.

Weick, K. E. (1993). Organizational redesign as improvisation. Organizational Change and Redesign: Ideas and Insights for Improving Performance, 346, 379.

Witell, L., Kristensson, P., Gustafsson, A., \& Löfgren, M. (2011). Idea generation: Customer co-creation versus traditional market research techniques. Journal of Service Management, 22(2), 140-159.

Witell, L., Snyder, H., Gustafsson, A., Fombelle, P., \& Kristensson, P. (2016). Defining service innovation: A review and synthesis. Journal of Business Research, 69(8), 2863-2872. 